\title{
Comparative activity of daptomycin and teicoplanin against enterococci isolated from blood and urine
}

\author{
KEVIN R FORWARD, MD, FRCPC, PATRICIA DEGAGNE, RT, \\ KATHRYN R BARTLET, BSC, RT, GODFREY K HARDING, MD, FRCPC
}

\begin{abstract}
KR Forward, P DeGagne, KR Bartlett, GK Harding. The comparative activity of daptomycin and teicoplanin against enterococci isolated from blood and urine. Can J Infect Dis 1992;3(4):173-178. The authors compared the activity of daptomycin with that of ampicillin, penicillin, teicoplanin and vancomycin against 304 strains of Enterococcus species isolated from blood and urine. Daptomycin was as active as penicillin against Enterococcus faecalis: $90 \%$ of strains were inhibited by $2 \mathrm{mg} / \mathrm{L}$. Daptomycin was more active than vancomycin (90\% minimal inhibitory concentration [MIC90] $2 \mathrm{mg} / \mathrm{L} ; 90 \% \mathrm{minimal}$ bactericidal concentration [MBC90] $8 \mathrm{mg} / \mathrm{L}$ ) but was less active than teicoplanin (MIC50 0.25; $\mathrm{MBC}_{90} 8$ $\mathrm{mg} / \mathrm{L}$ ) or ampicillin (MIC90 $1 \mathrm{mg} / \mathrm{L}$; MBC90 $2 \mathrm{mg} / \mathrm{L}$ ) against $E$ faecalis. In time-kill studies daptomycin was not more rapidly bactericidal than ampicillin or penicillin but was significantly more rapidly bactericidal than either teicoplanin or vancomycin. In combination with gentamicin, daptomycin has activity similar to that of penicillin, vancomycin and teicoplanin. Daptomycin may be a suitable alternative to penicillin in patients allergic to penicillins or for the treatment of enterococcal infections caused by beta-lactamaseproducing enterococci.
\end{abstract}

Key Words: Daptomycin, Enterococci, Enterococcus faecalis, Teicoplanin

\section{Activité comparative de la daptomycine et de la teicoplanine contre les entérocoques isolés dans le sang et l'urine}

RÉSUMÉ: Les auteurs ont comparé l'activité de la daptomycine à celle de l'ampicilline, de la pénicilline, de la teicoplanine et de la vancomycine contre 304 souches d'entérocoques isolés dans le sang et l'urine. La daptomycine était aussi active que la pénicilline contre Enterococcus faecalis, $90 \%$ des souches étant inhibées par $2 \mathrm{mg} / \mathrm{L}$. La daptomycine était plus active (concentration minimale inhibitrice de $90 \%$ [CMI90] à $2 \mathrm{mg} / \mathrm{L}$; concentration minimale bactéricide de $90 \%$ [CMB90] à $8 \mathrm{mg} / \mathrm{L}$ ) que la vancomycine mais moins que la teicoplanine (CMI9o à $1 \mathrm{mg} / \mathrm{L}$; CMBgo à $2 \mathrm{mg} / \mathrm{L}$ ) contre $E$ faecalis. Des essais ont déterminé que l'action bactéricide de la daptomycine n'était pas plus rapide que celle de l'ampicilline ou de la pénicilline mais qu'elle était significativement plus rapide que celle de la teicoplanine ou de la vancomycine. En association avec la gentamycine, la daptomycine a une activité similaire à celle de la pénicilline, de la vancomycine et de la teicoplanine. La daptomycine peut être une solution de rechange appropriée dans le cas de patients allergiques aux pénicillines ou dans le traitement des infections causées par des entêrocoques producteurs de bêta-lactamases.

Departments of Medicine and Laboratory Medicine, St Boniface General Hospital, Winnipeg, Manitoba

Correspondence and reprints: Dr KR Forward, Department of Microbiology, Victoria General Hospital, 5788 University Avenue,

Halifax, Nova Scotia B3H 1 V8. Telephone (902) 428-3624

Received for publication July 27, 1990. Accepted February 21, 1991 
E TEROCOCCI ARE AN INCREASINGLY IMPORTANT CAUSE OF serious infections in hospitalized patients (1). This increase may be attributed in part to the widespread use of third generation cephalosporins and monobactams in the past decade (2-5). Accompanying this increase in prevalence has been the rapid emergence of enterococci which produce aminoglycoside-inactivating enzymes and are resistant to the synergistic interaction of aminoglycosides and penicillin (6-9). Enterococcal strains resistant to penicillins either by virtue of their ability to produce beta-lactamase or by the development of altered penicillin-binding proteins are also being recovered with increasing frequency (10-14). These strains are also resistant to the synergistic interaction of aminoglycosides and penicillins. Recently, Leclercq et al (15) described two strains of Enterococcus faecium resistant to both vancomycin and teicoplanin.

Because of the emergence of antibiotic resistance among enterococci, and since many patients are penicillin allergic, alternate antibiotics are needed for the treatment of patients with serious enterococcal infections. The authors compared the activities of daptomycin, teicoplanin, penicillin, ampicillin and vancomycin against Enterococcus species isolated from patients with bacteremia and urinary tract infections.

\section{MATERIALS AND METHODS}

Organisms: A total of 304 isolates from blood and urine cultures were collected over a five year period from patients seen at St Boniface General Hospital and the Health Sciences Centre in Winnipeg, Manitoba. Of these, 141 were from blood cultures and 163 were urine isolates. Organisms were presumptively identified as Enterococcus species using esculin hydrolysis and 6.5\% sodium chloride tolerance (16). The organisms were subsequently identified to species level based on carbohydrate consumption (16). All stocks were kept at $-70^{\circ} \mathrm{C}$ in skim milk.

Antimicrobial agents: Gentamicin, vancomycin, daptomycin, teicoplanin, penicillin and ampicillin were supplied as standard laboratory powders by their respective manufacturers. All solutions were prepared according to manufacturers' instructions.

Determination of MICs/MBCs: Minimal inhibitory concentrations (MICs) were determined by the microtitre technique using cation-supplemented MuellerHinton broth (Difco Laboratories, Michigan) at pH 7.2 with a final volume of $0.1 \mathrm{~mL}$ per well. Antimicrobial agents were tested over a range of twofold concentration increments from 0.12 to $256 \mathrm{mg} / \mathrm{L}$. Microtitre plates were stored at $-70^{\circ} \mathrm{C}$ and used within three weeks of preparation.

The inoculum was standardized using a number 1 McFarland turbidity standard. This was diluted 1:10 using sterile water. A Dynatech MIC 2000 inoculator (Dynatech Laboratories, Virginia) was used to deliver $0.001 \mathrm{~mL}$ to each well. The final concentration of or-
TABLE 1

Comparative susceptibilities of daptomycin, teicoplanin and three other agents against Enterococcus species

\begin{tabular}{|c|c|c|c|c|c|c|}
\hline \multirow[b]{2}{*}{ Antibiotic } & \multicolumn{3}{|c|}{$\mathrm{MIC}(\mathrm{mg} / \mathrm{L})$} & \multicolumn{3}{|c|}{$\mathrm{MBC}(\mathrm{mg} / \mathrm{L})$} \\
\hline & Range & $50 \%$ & $90 \%$ & Range & $50 \%$ & $\% 90 \%$ \\
\hline \multicolumn{7}{|c|}{ Enterococcus faecalis $(\mathrm{n}=281)$} \\
\hline Daptomycin & $\leq 0.06$ to 4 & 1 & 2 & $\leq 0.06$ to 8 & 4 & 8 \\
\hline Teicoplanin & $\leq 0.06$ to 0.5 & $\leq 0.06$ & 0.25 & $\leq 0.06$ to 16 & 4 & 8 \\
\hline Penicillin & 0.5 to 4 & 2 & 2 & 2 to $\geq 64$ & 4 & 8 \\
\hline Ampicillin & 0.25 to 2 & 1 & 1 & 0.5 to 32 & 1 & 2 \\
\hline Vancomycin & 0.5 to 4 & 2 & 4 & 4 to $\geq 64$ & 16 & $\geq 64$ \\
\hline \multicolumn{7}{|c|}{ Enterococcus faecium $(n=18)$} \\
\hline Daptomycin & 0.25 to 8 & 2 & 4 & 1 to 16 & 4 & 8 \\
\hline Teicoplanin & 0.25 to 1 & 0.25 & 0.5 & 2 to 16 & 8 & 16 \\
\hline Penicillin & 0.25 to 16 & 2 & 4 & 0.5 to 16 & 4 & 16 \\
\hline Ampicillin & 0.25 to 4 & 1 & 1 & 0.5 to 16 & 2 & 8 \\
\hline Vancomycin & 0.5 to 16 & 1 & 8 & 8 to $\geq 64$ & 16 & $\geq 64$ \\
\hline \multicolumn{7}{|c|}{ Other Enterococcus species $(n=5)$} \\
\hline Daptomycin & 0.25 to 2 & & & 0.25 to 4 & & \\
\hline Teicoplanin & $\leq 0.06$ to 0.5 & & & 2 to 8 & & \\
\hline Penicillin & $\leq 0.06$ to 16 & & & $\leq 0.06$ to 16 & & \\
\hline Ampicillin & $\leq 0.06$ to 8 & & & $\leq 0.06$ to 8 & & \\
\hline Vancomycin & 0.5 to 1 & & & 4 to 8 & & \\
\hline
\end{tabular}

MBC Minimal bactericidal concentration: MIC Minimal inhibitory concentration

ganism was $10^{5}$ colony forming units (CFU)/mL. Plates were incubated at $35^{\circ} \mathrm{C}$ for 18 to $24 \mathrm{~h}$ in ambient air. The MIC was considered to be the lowest concentration of antibiotic resulting in no visible growth in the microtitre well. Minimal bactericidal concentrations (MBCs) were performed by subculturing $0.01 \mathrm{~mL}$ from each well and spreading it onto the surface of a sheep blood agar plate. The MBC was defined as the lowest antibiotic concentration resulting in a 99.9\% reduction in the original inoculum. Strains were considered tolerant if the MBC/MIC ratio was 32 or greater. Staphylococcus aureus ATCC 25923, 29213 and Staphylococcus faecalis ATCC 29212 were used as control strains.

Time-kill procedures: Twenty-five blood culture strains of Enterococcus faecalis from both centres displaying high level resistance to gentamicin (MIC greater than $500 \mathrm{mg} / \mathrm{L}$ ) were used in the performance of kill curves. Final concentrations of antibiotics were 2 and 5 $\mathrm{mg} / \mathrm{L}$ for daptomycin and $10 \mathrm{mg} / \mathrm{L}$ for vancomycin. teicoplanin, ampicillin and penicillin. Antibiotic concentrations chosen were based upon readily achievable serum concentrations. Cation-supplemented MuellerHinton broth containing the appropriate antibiotics was dispensed in $10 \mathrm{~mL}$ volumes. A growth control without antibiotics was included in each run. The inoculum (mid logarithmic phase) was standardized against a $0.5 \mathrm{Mc}$ Farland standard and diluted 1:10 in sterile broth. The inoculum $(0.1 \mathrm{~mL})$ was added to each tube to achieve a final concentration of $10^{5} \mathrm{CFU} / \mathrm{mL}$. The stationary tubes were incubated at $37^{\circ} \mathrm{C}$ in ambient air and were sampled at $0,4,24$ and $48 \mathrm{~h}$. 


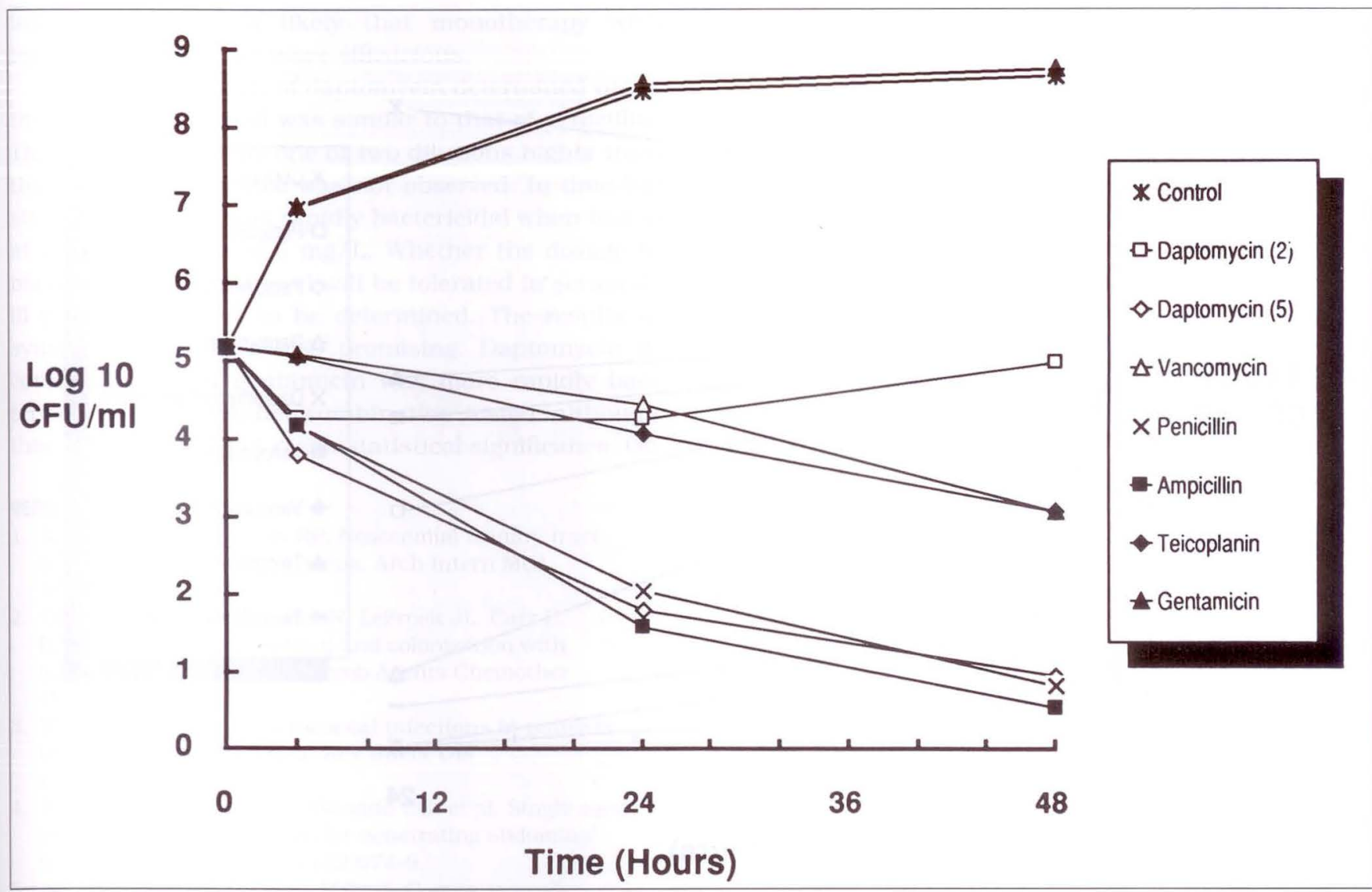

Figure 1) Time-kill curves of 25 isolates of Enterococcus faecalis. Daptomycin was tested at 2 and 5 mg/L. Other antibiotics were tested at $10 \mathrm{mg} / \mathrm{L}$. CFU Colony forming units

Colony counts were performed by transferring 0.1 $\mathrm{mL}$ of broth to the surface of sheep blood agar plates. Plates were incubated at $37^{\circ} \mathrm{C}$ for $18 \mathrm{~h}$ and colony counts performed.

Time-kill synergy studies were performed on six blood culture isolates. Daptomycin, vancomycin, teicoplanin and penicillin were compared, each in combination with gentamicin against six $E$ faecalis strains not highly resistant to gentamicin. For the synergy studies, the vancomycin, teicoplanin and penicillin concentrations were $10 \mathrm{mg} / \mathrm{L}$; the daptomycin and gentamicin concentrations were $5 \mathrm{mg} / \mathrm{L}$. The method was otherwise as described for kill curves, with the exception that no sampling was done at $48 \mathrm{~h}$.

In order to compare bacterial survival in kill curve studies, a 'repeated measures' analysis of variance comparing counts at each point using 'least square' means and adjusted for multiple comparisons via Bonferroni adjustments was used.

\section{RESULTS}

The authors determined susceptibilities of 304 Enterococcus species strains: 141 from blood and 163 from urine. Two hundred and eighty-one strains were $E$ faecalis, 18 were $E$ faecium and five were other Enterococcus species. Twenty-seven $E$ faecalis isolates
(19.0\%) from blood were highly resistant to gentamicin (MIC greater than or equal to $500 \mathrm{mg} / \mathrm{L}$ ), as were 12 isolates from urine. Table 1 shows the comparative activity of daptomycin, teicoplanin and other agents against the 304 strains tested. Teicoplanin was the most active agent with an MIC90 of $0.25 \mathrm{mg} / \mathrm{L}$; however, the $\mathrm{MBC} 90$ was $8 \mathrm{mg} / \mathrm{L}$ and 256 strains were tolerant of teicoplanin. The $\mathrm{MIC}_{50}$, MIC90 and $\mathrm{MBC}_{90}$ for daptomycin were 1,2 and $8 \mathrm{mg} / \mathrm{L}$ and compared favorably with those of penicillin (2, 2 and $8 \mathrm{mg} / \mathrm{L}$, respectively). No strain was tolerant of daptomycin and only one strain was tolerant of ampicillin and penicillin. Vancomycin was the least active of the agents tested with an MIC90 of $4 \mathrm{mg} / \mathrm{L}$ and an MBC90 of $64 \mathrm{mg} / \mathrm{L}$. Thirty strains were tolerant of vancomycin. The comparative activities of the agents tested determined by time-kill method are shown in Figure 1. Daptomycin $(2 \mathrm{mg} / \mathrm{L})$, vancomycin and teicoplanin were relatively bacteriostatic, resulting in a one $\log _{10}$ fall in count from the original inoculum. Penicillin, ampicillin and daptomycin at $5 \mathrm{mg} / \mathrm{L}$ were more rapidly bactericidal, each resulting in 1000-fold reductions in counts. After 24 and $48 \mathrm{~h}$, killing of enterococci was not different between penicillin and daptomycin $(5 \mathrm{mg} / \mathrm{L})(\mathrm{P}>0.05)$ but was significantly greater than that of vancomycin, teicoplanin or daptomycin $(2 \mathrm{mg} / \mathrm{L})(\mathrm{P}<0.05)$. 


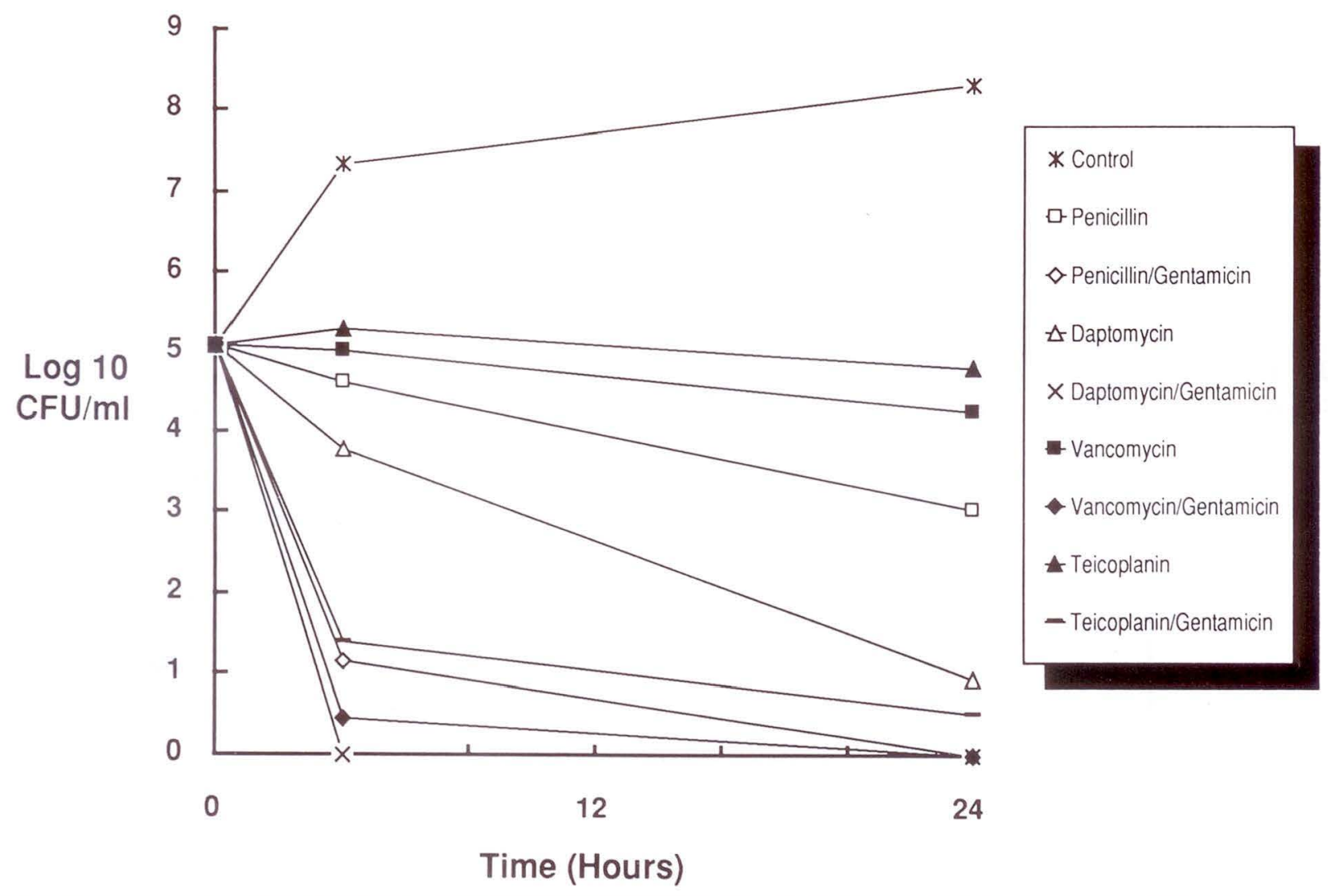

Figure 2) Time-kill synergy curves performed in six strains of Enterococcus faecalis not highly resistant to gentamicin. Daptomycin and gentamicin were tested at $5 \mathrm{mg} / \mathrm{L}$. Other antibiotics were tested at $10 \mathrm{mg} / \mathrm{L}$. CFU Colony forming units

The results of time-kill synergy studies are shown in Figure 2. After $4 \mathrm{~h}$, daptomycin $(5 \mathrm{mg} / \mathrm{L})$ in combination with gentamicin (5 mg/L) was most rapidly bactericidal, although the counts were not statistically significantly different from penicillin, vancomycin or teicoplanin each in combination with gentamicin. The daptomycingentamicin combination was the only one which resulted in a sterile broth after $4 \mathrm{~h}$ incubation. Teicoplanin, penicillin and vancomycin each combined with gentamicin also resulted in a synergistic interaction, ie, the number of viable cells was 10 -fold lower than the more effective antibiotic used alone. The geometric mean counts after $4 \mathrm{~h}$ were 48,14 and $3 \mathrm{CFU} / \mathrm{mL}$, respectively. After $24 \mathrm{~h}$, daptomycin, penicillin and vancomycin each combined with gentamicin were sterile. The teicoplanin-gentamicin combination was not; the geometric mean count was $4 \mathrm{CFU} / \mathrm{mL}$. After $24 \mathrm{~h}$, daptomycin $(5 \mathrm{mg} / \mathrm{L})$ alone was not statistically different from teicoplanin, penicillin or vancomycin in combination with gentamicin $(\mathrm{P}>0.05)$.

\section{DISCUSSION}

The emergence of high level resistance to both aminoglycosides and penicillins makes treatment of serious enterococcal infections increasingly difficult. The present authors observed, as have others, that vancomycin was relatively bacteriostatic against a significant proportion of strains of enterococci (17-19). However, combined with gentamicin, vancomycin was as effective as the combination of penicillin and gentamicin. Although vancomycin alone may cure many serious enterococcal infections including endocarditis, many physicians recommend its use in combination with an aminoglycoside (20-24). In addition, vancomycin use may be associated with adverse reactions; less toxic antibiotics are needed (23).

Teicoplanin is a new cell-wall-active glycopeptide antibiotic with activity against Gram-positive bacteria including Enterococcus species (25-27). Although MICs were usually lower than for other agents tested, most strains were tolerant. The MBC9o was still below serum levels achieved with intravenous administration and lower than the concentration used in other kill curve studies (28). In time-kill studies the concentration tested did not result in significant bactericidal activity. Therapy with teicoplanin may be complicated somewhat by the observation that serum levels may not be predictable in seriously ill patients (29). In a rabbit model of enterococcal endocarditis teicoplanin is no more effective than ampicillin in the sterilization of vegetations (30). Since ampicillin alone is frequently inadequate for the treatment of serious enterococcal 
infections, it seems likely that monotherapy with teicoplanin will be no more efficacious.

The in vitro activity of daptomycin determined using the microtitre method was similar to that of penicillin. The MBC was usually one or two dilutions higher than the MIC, and tolerance was not observed. In time-kill studies this agent was rapidly bactericidal when tested at a concentration of $5 \mathrm{mg} / \mathrm{L}$. Whether the dosage to maintain this serum level will be tolerated in seriously ill patients remains to be determined. The results of synergy testing were also promising. Daptomycin in combination with gentamicin was more rapidly bactericidal than any other combination tested, although this difference did not reach statistical significance. On

\section{REFERENCES}

1. Morrison AJ Jr, Wenzel RP. Nosocomial urinary tract infections due to enterococcus. Arch Intern Med 1986:146:1549-51

2. Chandrasekar PH, Smith BR, LeFrock JL, Carr B. Enterococcal superinfection and colonization with aztreonam therapy. Antimicrob Agents Chemother 1984:26:280-2.

3. Moellering RC Jr. Enterococcal infections in patients treated with moxalactam. Rev Infect Dis 1982;4:S708-11.

4. Feliciano DV, Gentry LO, Bitondo CG, et al. Single agent cephalosporin prophylaxis for penetrating abdominal trauma. Am J Surg 1986;152:674-9.

5. Leoung GS, Chaisson RE, Mills J. Comparison of nosocomial infections due to Staphylococcus aureus and enterococci in a general hospital. Surg Gynecol Obstet 1987; 165:339-42.

6. Murray BE, Tsao J, Panida J. Enterococci from Bangkok, Thailand, with high-level resistance to currently available aminoglycosides. Antimicrob Agents Chemother 1983:23:799-802.

7. Mederski-Samoraj BD, Murray BE. High-level resistance to gentamicin in clinical isolates of enterococci. J Infect Dis 1983;147:751-7.

8. Zervos MJ, Terpenning MS, Schaberg DR, Therasse PM, Medendorp SV, Kauffman CA. High-level aminoglycosideresistant enterococci: Colonization of nursing home and acute care hospital patients. Arch Intern Med 1987;147:1591-4

9. Zervos MJ, Kauffman CA, Therasse PM, Bergman AJ, Mikesell TS, Schaberg DR. Nosocomial infection by gentamicin-resistant Streptococcus faecalis: An epidemiologic study. Ann Intern Med 1987;106:687-91.

10. Calmon J, Bush L, Cherney C, Wendeler M. High-level penicillin resistance among strains of Enterococcus faecium. 28th Interscience Conference on Antimicrobial Agents and Chemotherapy, California, 1988:157. (Abst)

11. Rupar D, Fisher MC, Marri L, Fletcher H, Mortensen J. Enterococcal isolates with high level resistance to ampicillin. Abstracts of the Annual Meeting of the American Society for Microbiology, Florida, 1988.

12. West LA, White ML. Ampicillin and penicillin G resistance in clinical isolates of Enterococcus species. Abstracts of the Annual Meeting of the American Society for Microbiology, Florida, 1988.

13. Murray BE, Church DA, Wanger A, et al. Comparison of two lactamase-producing strains of Streptococcus faecalis. Antimicrob Agents Chemother 1986;30:861-4. 14. Murray BE, Mederski-Samoraj B. Transferable beta- the other hand, Miniter et al (31) observed that daptomycin-gentamicin was less frequently synergistic than penicillin-gentamicin using the checkerboard technique of measuring antibiotic interaction. They also observed that in a mouse pyelonephritis model, daptomycin alone or in combination with gentamicin was less active than ampicillin alone or in combination.

Clearly, other animal studies and subsequent human trials are necessary to determine the role to be played by either daptomycin or teicoplanin in the antibiotic armamentarium. Whether physicians will choose to use these agents in serious enterococcal infections will depend upon the results of studies in animal models.

lactamase. A new mechanism for in-vitro penicillin resistance in Streptococcus faecalis. J Clin Invest 1983;72:1168-71.

15. Leclercq R, Derlot E, Duval J, Courvalin P.

Plasmid-mediated resistance to vancomycin and teicoplanin in Enterococcus faecium. N Engl J Med 1988;319:157-61.

16. Facklam RR, Carey RB. Streptococci and aerococci. In: Lenette EH, Balows A, Hausler WJ Jr, Shadomy HJ, eds. Manual of Clinical Microbiology, 4th edn. Washington: American Society for Microbiology, 1985:154-75.

17. Harwick HJ, Kalmanson GM, Guze LB. In vitro activity of ampicillin or vancomycin combined with gentamicin or streptomycin against enterococci. Antimicrob Agents Chemother 1973;4:383-7.

18. Barriere SL, Lutwick LI, Jacobs RA, Conte JE. Vancomycin treatment of enterococcal meningitis. Arch Neurol 1985;42:686-8.

19. Mandell GL, Hook LE. Synergism of vancomycin and streptomycin for enterococci. Am J Med Sci 1970;259:346-9.

20. Westenfelder GO, Paterson PY, Resiberg BE, et al. Vancomycin-streptomycin synergism in enterococcal endocarditis. JAMA 1973:223:37-40.

21. Hook EW III, Johnson WD Jr. Vancomycin therapy of bacterial endocarditis. Am J Med 1978;65:411-5.

22. Cook FV, Coddington CC, Wadland NC, et al. Treatment of bacterial endocarditis with vancomycin. Am J Med Sci 1978;276:153-8.

23. Mandell GL, Kaye D, Levison ME, Hook EW. Enterococci endocarditis: An analysis of 38 patients observed at the New York Hospital-Cornell Medical Center. Arch Intern Med 1970;125:258-64.

24. Friedberg CK, Rosen KM, Bienstock PA. Vancomycin therapy for enterococcal and Streptococcus viridans endocarditis. Successful treatment of six patients. Arch Intern Med 1968;122:134.

25. Parenti F, Beretta G, Berti M, Arioti V. Teichomycins, new antibiotics from Actinoplanes teichomyceticus sp nov. I. Description of the producer strain, fermentation studies and biological properties. J Antibiot 1978;31:276-83.

26. Tuazon CU, Miller H. Comparative in vitro activities of teichomycin and vancomycin alone and in combination with rifampin and aminoglycosides against staphylococci and enterococci. Antimicrob Agents Chemother 1984:25:411-2.

27. Cynamon $\mathrm{MH}$, Granato PA. Comparison of the in vitro activities of teichomycin A2 and vancomycin against staphylococci and enterococci. Antimicrob Agents Chemother 1982;21:504-5. 
28. Bibler MR, Frame PT, Hagler DN, et al. Clinical evaluation of efficacy, pharmacokinetics, and safety of teicoplanin for serious Gram-positive infections. Antimicrob Agents Chemother 1987;31:207-12.

29. Calan P, Krause KH, Vaudaux P, et al. Early termination of a prospective, randomized trial comparing teicoplanin and flucloxacillin for treating severe staphylococcal infections. J Infect Dis 1987:155:187-91.
30. Sullam PM, Tauber MG, Hackbarth CJ, Sande MA. Therapeutic efficacy of teicoplanin in experimental enterococcal endocarditis. Antimicrob Agents Chemother 1985;27:135-6.

31. Miniter PM, Patterson TF, Johnson MA, Andriole VT. Activity of LY146032 in vitro and in experimental enterococcal pyelonephritis. Antimicrob Agents Chemother 1987:31:1199-203. 


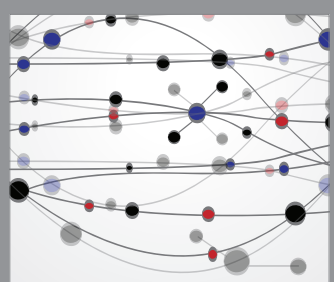

The Scientific World Journal
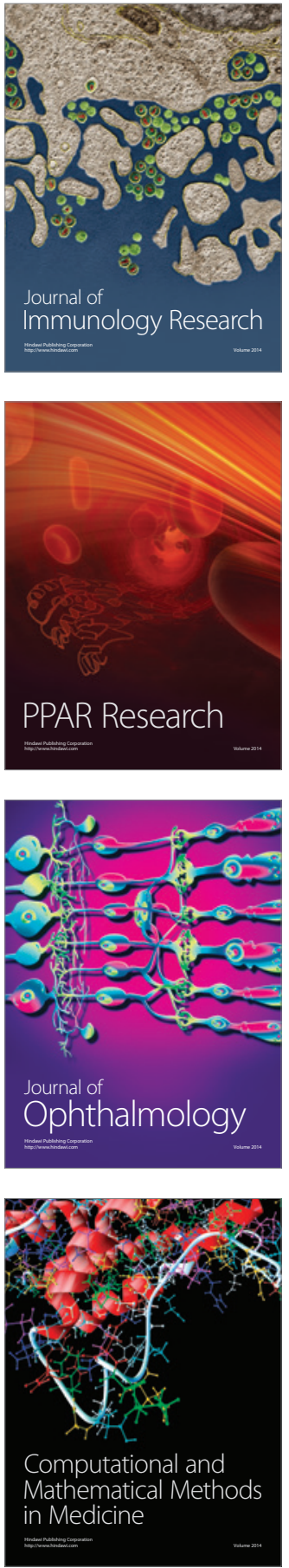

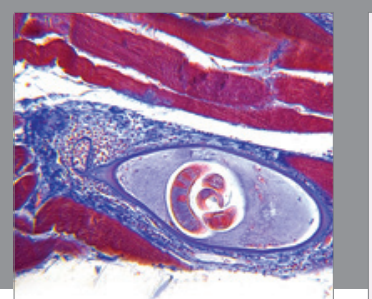

Gastroenterology Research and Practice

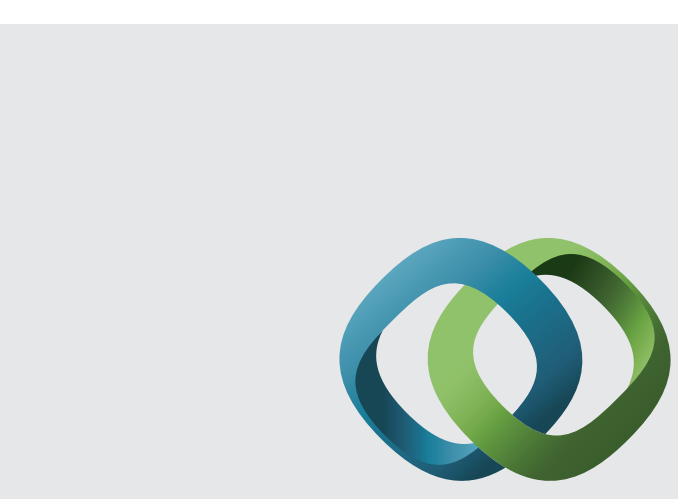

\section{Hindawi}

Submit your manuscripts at

http://www.hindawi.com
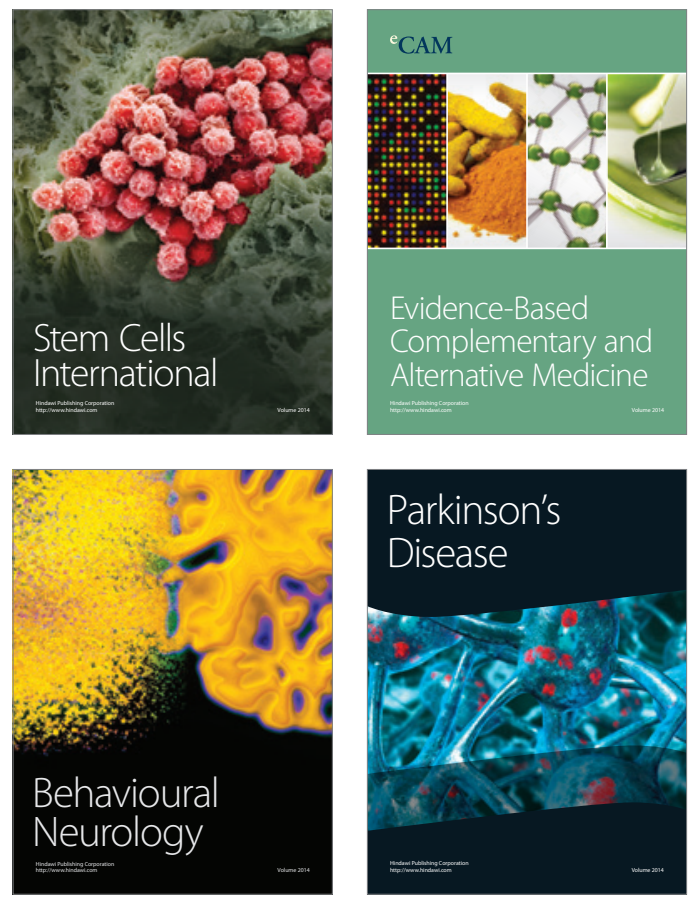
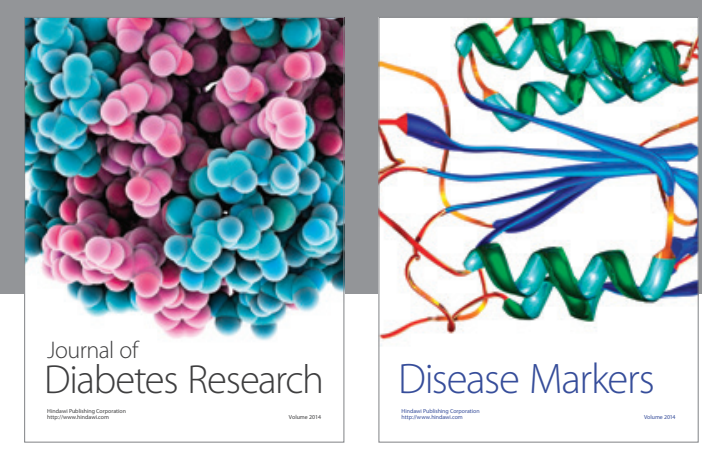

Disease Markers
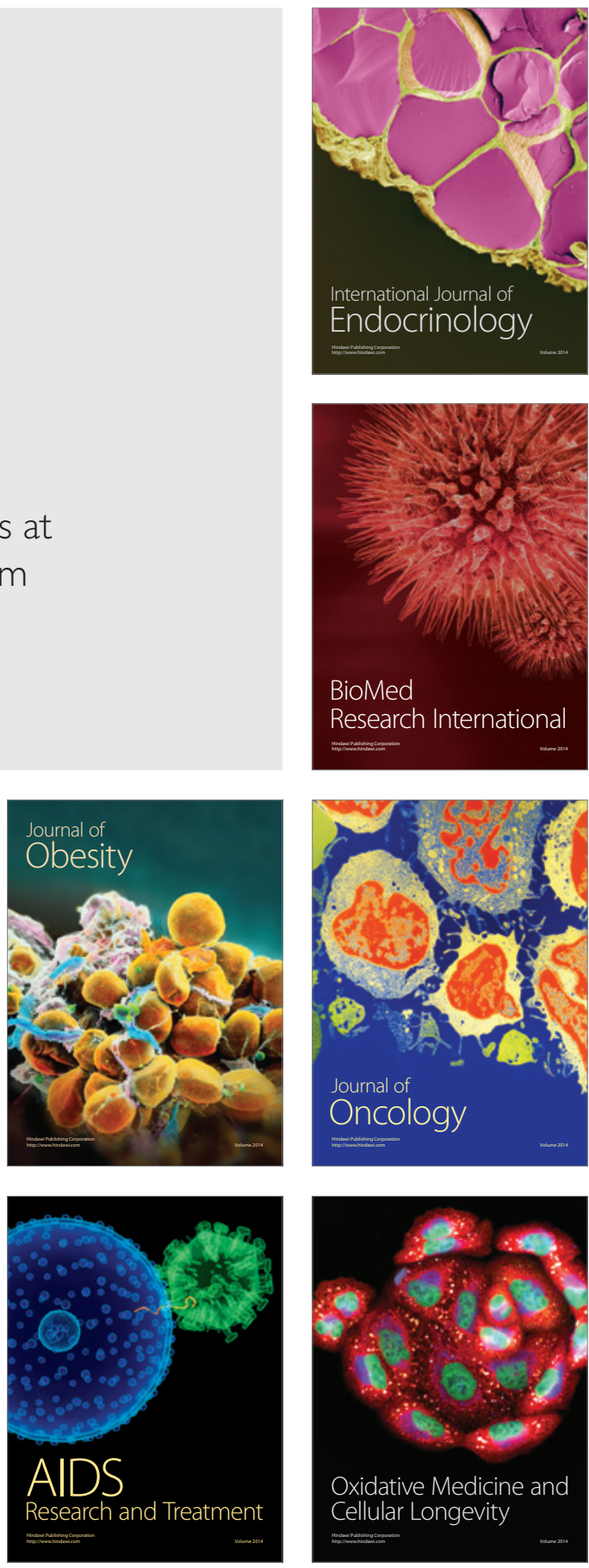